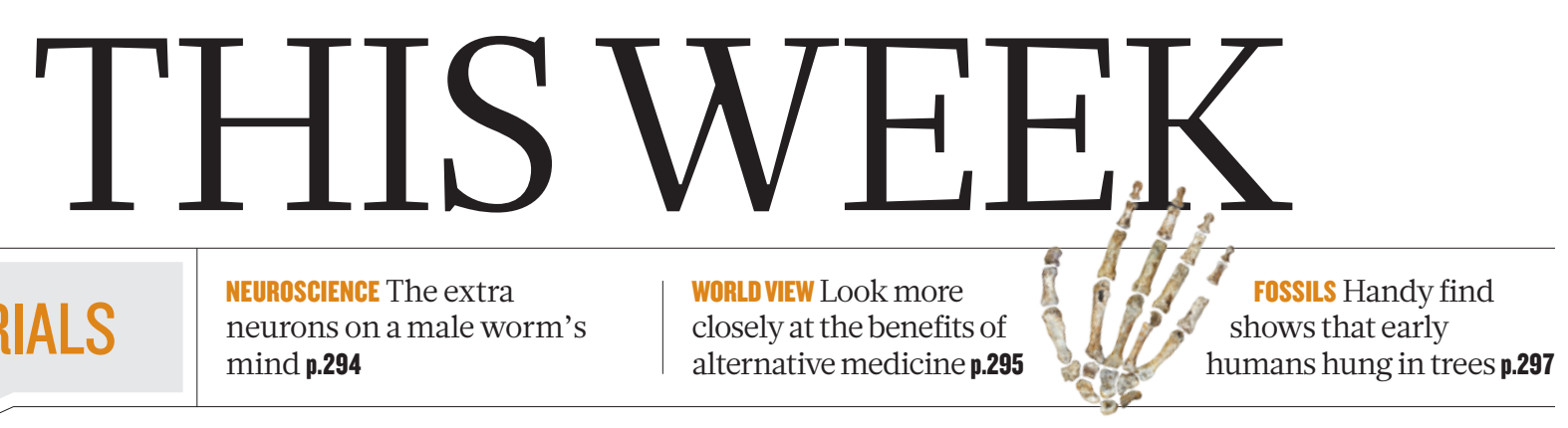

EDITORIALS neurons on a male worm's mind p.294

\title{
A shift in climate
}

\section{The Intergovernmental Panel on Climate Change has done much to alert politicians to the effects of global warming. But to push climate change up the agenda, it will need to do the same for the public.}

$\mathrm{H}$ oesung Lee has laid out a vision for his tenure as the fourth chair of the Intergovernmental Panel on Climate Change (IPCC). The South Korean economist says that he wants to increase coordination between the working groups, work with more scientists from developing countries, boost interaction with the business and financial industries and expand the panel's influence by making its findings easier to digest. Above all, Lee says that he wants to be remembered as the man who shifted the panel's focus towards solutions. Those are all worthy goals, but the organization that assesses - and in some senses oversees - the world of climate science is well placed to do a lot more.

The basic science underlying climate change has been firmly established, and we now know much more about not only the threats posed by a rapidly warming world, but also the options humanity has for changing course. Even though the commitments that have been proffered going into the United Nations climate summit in Paris at the end of next month are generally tepid, the governments of the world by and large recognize the problem and know that they need to act. What else can the IPCC do? The answer is plenty, and Lee's emphasis on solutions is one piece of the puzzle.

Most of the world's major emitters - rich, poor and in between - have offered commitments and policies to move their countries in the right direction. Without concerted action in the decades to come, however, these commitments will fall well short of what the best science suggests is needed to achieve the formal goal of limiting the rise in global average temperatures to $2^{\circ} \mathrm{C}$. Political leaders are leaving the hard work for later, and could well be committing future generations to more warming than anybody wants to experience.

This is partly because of a lack of political leadership and of active opposition by entrenched industrial interests, as environmentalists argue. But it is also evidence of the vastness of the challenge. It is not easy to transform the global economy and industrial base for a large and growing population, much of which is still mired in poverty but wants access to the modern conveniences that so many on the planet take for granted. The world needs a full suite of technologies that are not only cost-effective but also socially and politically viable. Here, the IPCC has a particular part to play.

The weak commitments going into Paris are also evidence of a disconnect between scientists, who think that the evidence speaks for itself, and citizens and policymakers, who have a lot of other things on their minds. The IPCC is looking at bringing science writers and graphics experts on board in an effort to improve its reports. A linguistics study published earlier this month showed that the IPCC summaries for policymakers score low in terms of readability, and recommends that key panel members receive science-communication training (R. Barkemeyer et al. Nature Clim. Change http://doi.org/79f; 2015). All this makes sense, but communicating the science more clearly is just the first, and a relatively minor, step.
The IPCC's reports are aimed mainly at — and written in coordination with - governments, yet politicians at the very highest levels are already talking about climate change. The unfortunate truth is that taking steps to combat climate change is way down the political agenda, and that makes more aggressive action difficult. The real challenge is to raise public awareness about the risks of inaction - as well as the benefits of action - and to identify policies that can pass the political litmus test.

Here, as Lee himself has said, the IPCC has an important role. The panel must generate and incorporate knowledge about how infor-
"The real challenge is to raise public awareness about the risks of inaction." mation filters through society and about the kinds of policies that are most likely to work. This is the domain of sociologists, psychologists, anthropologists and political scientists, and they must be an integral part of the IPCC's sixth assessment.

The IPCC has had its controversies, including a glitch in its 2007 projection for Himalayan glacier melt and this year's resignation of former chairman Rajendra Pachauri, who faces - and denies - accusations of sexual harassment. But the challenges that face the panel today are in many ways a result of its success. Much ground has been covered; the challenge now, for both researchers and the IPCC, is to adapt and to identify research that will help policymakers to bridge the gap between what they say they want to do and what they are actually doing.

\section{After Asilomar}

\section{Scientist-led conferences are no longer the best way to resolve debates on controversial research.}

I n 1975, some 140 scientists met at the Asilomar resort on California's rocky Monterey Peninsula to discuss the nascent science of mixing DNA from different organisms.

Until that point, researchers had deliberately not performed the final steps of such experiments, owing to concerns about safety and ethics. Over three days of discussions, the conference attendees agreed to voluntary restrictions on recombinant-DNA research, and drafted a document that listed the potential risks of such experiments and how to carry out the work safely.

The meeting is seen as the first time that science had regulated itself - effectively avoiding government intervention — and assuaged public fears by addressing biosafety concerns head-on.

Today, no scientific controversy is complete without calls for an 
'Asilomar-like' conference. Until such a conversation has taken place, proponents say, researchers should not proceed with risky propositions.

Debates on artificial intelligence, autonomous weapons, geoengineering and the use of gene-editing technology have all referred to Asilomar as a useful model. (Geoengineers went so far as to meet in Asilomar.) This month, a group of scholars, programmers, artists, entrepreneurs and video-game developers published a Biosphere Code to protect people and the planet from the negative impact of computer algorithms - produced after Asilomar-like discussions in Stockholm.

But is Asilomar's reputation deserved? The invitation-only conference included a handful of journalists and policymakers, but did not cast a wide net outside the scientific community. And in hindsight, many of its safety precautions may have been overkill. As bioethicist Jonathan Moreno puts it: "Asilomar has become a bio-Woodstock in people's memories, a golden age. People forget how muddy Woodstock was."

Modern science is muddier still: in a 2008 essay in Nature, even Asilomar organizer Paul Berg admitted that such a conference would be difficult to convene today (P. Berg Nature 455, 290-291; 2008). In 1975, he and his colleagues had yielded to concerns from within their tight-knit community. They could afford to pause their research, having reasonable certainty that the technology would not advance in the meantime.

But like everything else in the twenty-first century, science has become a global affair. An enormous number of researchers have almost unfettered access to information and increasingly easy-to-use tools. As a result, 'synthetic' organisms, enhanced influenza viruses and genetically modified human embryos already exist, whether the world is ready for them or not. Even if they are destroyed, the instructions to make them will inevitably make their way onto the Internet a technology as pervasive and uncontrollable as any biological entity.

Modern science is also less insular than that of the past, and any single Asilomar conference would probably be lost in the noise. New players have appeared over the past four decades, including a powerful biotechnology industry driven at least in part by profit; the most polarized US government in history, which can turn any new technology into a political weapon; and a mass of religious and activist groups that have flexed their muscles to stop research on embryonic stem cells and genetically modified organisms in their tracks.

Each represents and interacts separately with the general public. And scientists who wish to self-regulate ignore public outcry at their peril: crowd-pleasing politicians passing knee-jerk regulations will hinder scientific progress more than any voluntary moratorium ever could, and their poor understanding might cause collateral damage to related fields.

\section{"When controversy comes calling, scientists should reach outwards."}

When controversy comes calling, rather than asking for an Asilomar conference which, after all, was closed to the public scientists should reach outwards. Discussions should extend beyond researchers and ethicists to include, or at least broadcast to, the broader public. Proactive engagement with the mass media is key: the most transparent of webcasts is meaningless if only a rarified group of already-interested individuals knows that the meeting is happening.

The most important thing is to communicate the risks and benefits of controversial research in a responsible and transparent way. For embryo editing, for instance, discussions should avoid unhelpful references to the genetically modified humans in the 1997 film Gattaca, or veiled aspersions on the ethical standards of non-Western researchers.

A modern Asilomar might also take advantage of the wide range of expertise and techniques available today. Some advisory bodies, such as the US National Academies' committee on research that involves enhancing influenza viruses, have had the forethought to include economists and futurists expert in drawing up realistic risk-benefit analyses and scenarios. Other strategies could include a war-game approach similar to the 2001 Dark Winter exercise, in which US media, government officials, health experts and military groups simulated a bioterror attack to anticipate the problems that would arise.

In 1975, the week after the Asilomar conference, actor Telly Savalas - star of the detective programme Kojak - topped the UK music charts with a spoken-word version of If by rock group Bread. The world has moved on since then; science must as well.

\section{The worm returns}

\author{
The wiring diagram of the male nematode's \\ nervous system is only a beginning.
}

$\mathrm{W}$ hen scientists seemed to have completed the map of the nervous system of a tiny male worm in 2012 (T. A. Jarrell et al. Science 337, 437-444; 2012), some researchers were already questioning whether the whole effort, originating some 40 years before, was truly worth it. The construction of the wiring diagram for the nervous system of the male of the nematode species Caenorhabditis elegans built on the wiring diagram for the hermaphrodite, established more than 25 years earlier, and required painstaking tracing of how the male worm's extra neurons connected to each other.

Stephen Hawking was talking metaphorically when he famously wrote that to unravel the laws of nature would be to know the mind of God. The C. elegans project was quite literal: as Sydney Brenner, the originator of the project, jokingly entitled the manuscript of a landmark 1986 paper, the scientists really did want to know 'the mind of the worm'. And in doing so, they argued, they could learn more about how brains create behaviour in higher organisms all the way up to humans.

Can we really know the mind of a worm? Three years on we have an answer of sorts: possibly. In fact, it turns out that we did not even find all the neurons that comprise the male worm's mind. For on page 385, researchers including two of the 2012 team publish an appendix to the wiring diagram of the male C. elegans. As well as the 383 neurons already identified, they describe the discovery of neurons number 384 and 385 , which they found in the worm's head.

There is much to admire about the new work, not least that the researchers chose to call the new cells - mystery cells found in the male worms - MCMs. No metaphor there either. It stands for mystery cells of the male.

What's on a male nematode's MCMs? Not so much of a mystery as it turns out: sex. The new neurons have an old role, and help the worms to learn to prioritize the search for a mate over the need for food. When these neurons are put out of action, the male worms never discover the facts of life. The findings offer much more than a completion of the neural map of the male worm. In most organisms, sex-specific differences in behaviour extend to cognitive-like processes such as learning, which can aid reproductive success, but the underlying neural mechanisms are mostly unclear.

The discovery of the MCMs, and the subsequent experiments with them, link developmental and anatomical sex differences in highorder processing areas of the brain to sex-specific behaviour during learning. In doing so, they help to shed light on the neural basis of sex differences in behaviour. And they show that these neurons arise upon sexual maturation from specialized cells called glia - unlike other neurons in C. elegans and other invertebrates, which arise from epithelial or undifferentiated blast cells. $\rightarrow$ NATURE.COM To comment online, click on Editorials at: go.nature.com/xhunqv
Was the effort to trace out the connections between the male nematode's neurons worth it? Like all good maps, the wiring diagram of the C. elegans is best viewed as a starting point. The final destination is sure to surprise us. 